\title{
USP9X Gene
}

National Cancer Institute

\section{Source}

National Cancer Institute. USP9X Gene. NCI Thesaurus. Code C101574.

This gene plays a role in deubiquitination. 